\title{
Pendidikan Kesehatan pada Ibu Hamil tentang Anemia menggunakan Media Video di Kota Palangka Raya
}

\section{Health Education for Pregnant Women on Anemia using Video Media in Palangka Raya City}

Oktaviani*
Heti Ira Ayue
Department of Midwifery, Poltekkes
Kemenkes Palangka Raya, Palangka
Raya, Central Kalimantan, Indonesia
email: oktaviani@poltekkes-
palangkaraya.ac.id
Kata Kunci
Anemia
Informasi
Interaksi
Kelas ibu hamil
Media video
Keywords:
Anemia
Information
Interaction
Maternity class
Video media
Published: October 2021

\begin{abstract}
Abstrak
Anemia dalam kehamilan merupakan masalah kesehatan yang utama di negara berkembang dengan tingkat morbiditas tinggi pada ibu hamil, dan merupakan salah satu faktor risiko perdarahan postpartum. Salah satu wilayah Kota Palangka Raya dengan data asupan Fe rendah adalah Puskemas Jekan Raya. Asupan Fe rendah oleh ibu hamil, patut diduga sebagai indikasi faktor pencetus anemia pada masa kehamilan. Upaya yang dapat dilakukan untuk meningkatkan pengetahuan ibu hamil tentang anemia adalah melalui pemberian informasi atau pendidikan kesehatan dari tenaga kesehatan, terutama sekali media video, yang mengandung unsur gambar dan suara. Metode kegiatan pengabdian masyarakat dilaksanakan dengan 3 metode meliputi persiapan, pelaksanaan kegiatan dan evaluasi kegiatan. Kegiatan dilaksanakan melalui pertemuan kelas ibu hamil di Puskesmas Pembantu Bumi Palangka, Wilayah Kerja Puskemas Jekan Raya, Kota Palangka Raya. Media atau alat bantu yang digunakan pada pelaksanaan kegiatan yaitu alat tulis, laptop, proyektor dan video tentang pencegahan anemia pada ibu hamil. Kegiatan ini meningkatkan pengetahuan ibu hamil sebesar $80 \%$. Selain itu, kegiatan kelas ibu hamil juga sangat bermanfaat bagi ibu hamil karena meningkatkan interaksi antara ibu hamil dan petugas Kesehatan, selain itu juga sarana untuk berbagi informasi.
\end{abstract}

\begin{abstract}
In developing countries with high levels of morbidity in pregnant women, anemia is a significant health problem and is one of the risk factors for postpartum bleeding. One area with low Fe intake data in Palangka Raya City is Puskemas Jekan Raya. In pregnant women, the intake of Fe is low and thus should be suspected as an indication of the anemia triggering factor during pregnancy. Efforts to increase pregnant women's knowledge of anemia can be made through improving healthcare employees with information or health education; particularly video media consist of a combination of images and sounds. Three methods have been applied in the Community Service Activity Method, including the preparation, implementation of activities, and evaluation. The activity was carried out at the Puskemas Pembantu Bumi Palangka, Jekan Raya District, Palangka Raya City, using a class meeting of pregnant women. Media or aids used in performing these activities, such as paperwork, laptops, projectors, and videos on anemia prevention in pregnant women. This activity increases pregnant women's knowledge by $80 \%$. In addition, pregnant women's classroom activities are also very beneficial because they improve interaction and share information.
\end{abstract} (http://creativecommons.org/licenses/by-sa/4.0/). DOI: https://doi.org/10.33084/pengabdianmu.v6i6.2104

\section{PENDAHULUAN}

Anemia dalam kehamilan merupakan masalah kesehatan yang utama di negara berkembang dengan tingkat morbiditas tinggi pada ibu hamil (Tanziha et al., 2016). Di Indonesia diperkirakan prevalensi kejadian anemia pada ibu hamil sebesar 37,1\% dan proporsinya 
hampir sama antara di kawasan perkotaan (36,4\%) dan perdesaan (37,8\%) (Natalia et al., 2016). Sedangkan di Kota Palangka Raya prevalensi anemia pada ibu hamil dengan indikator Haemoglobin $(\mathrm{Hb}) 11$ gr\% adalah 14,56\% (Dinas Kesehatan Kota Palangka Raya, 2018).

Ibu hamil yang mengalami anemia meningkatkan risiko mengalami keguguran, melahirkan sebelum waktunya, bayi lahir dengan berat tidak normal, perdarahan sebelum serta pada waktu melahirkan dan pada anemia berat dapat menimbulkan kematian ibu dan bayi. Anemia merupakan salah satu faktor risiko perdarahan postpartum (Oktaviani, 2018). Upaya yang dapat dilakukan untuk meningkatkan pengetahuan ibu hamil tentang anemia adalah melalui pemberian informasi atau pendidikan kesehatan dari tenaga kesehatan (Sukmawati et al., 2019). Pendidikan kesehatan merupakan suatu kegiatan atau usaha menyampaikan informasi kesehatan kepada masyarakat, kelompok atau individu dengan harapan informasi tersebut dapat meningkatkan pengetahuan menjadi lebih baik. Media video merupakan media audiovisual merupakan media yang selain mengandung unsur suara juga mengandung unsur gambar yang dapat dilihat, seperti video (Alini \& Indrawati, 2018).

Puskesmas Jekan Raya merupakan salah satu Puskesmas di wilayah Kota Palangka Raya yang mempunyai jumlah ibu hamil 328 orang dengan cakupan Fe1 sebesar 28,35\% (93) dan Fe 3 sebesar 18,90\% (Dinas Kesehatan Kota Palangka Raya, 2018). Melihat data tersebut menunjukkan bahwa masih rendahnya ibu hamil dalam mengkonsumsi Fe sebagai upaya pencegahan anemia pada masa kehamilan. Berdasarkan latar belakang di atas akan dilaksanakan pengabdian masyarakat mengenai Upaya Pencegahan Anemia Pada Kehamilan Melalui Kelas Ibu Hamil Dengan Media Video di Wilayah Kerja Puskesmas Jekan Raya Palangka Raya.

\section{METODOLOGI}

Metode kegiatan pengabdian masyarakat dilaksanakan dengan 3 metode meliputi persiapan, pelaksanaan kegiatan dan evaluasi kegiatan. Kegiatan dilaksanakan melalui pertemuan kelas ibu hamil di Puskesmas Pembantu Bumi Palangka, Wilayah Kerja Puskemas Jekan Raya, Kota Palangka Raya. Media atau alat bantu yang digunakan pada pelaksanaan kegiatan yaitu alat tulis, laptop, LCD, dan video tentang pencegahan anemia pada ibu hamil.

\section{HASIL DAN PEMBAHASAN}

Proses pelaksanaan kegiatan pengabdian masyarakat telah dilaksanakan sesuai dengan tahapan pelaksanaan. Pada tahapan persiapan kegiatan dilakukan penjajakan dengan kepala Puskesmas dan bidan Puskesmas Jekan Raya dan diarahkan pelaksanaan pengabdian masyarakat pada Puskesmas Pembantu Bumi Palangka. Pelaksanaan pengabdian masyarakat melalui kegiatan kelas ibu hamil dilaksanakan dengan dihadiri 10 orang ibu hamil, didampingi 2 orang bidan Puskesmas Pembantu Bumi Palangka. Pada pelaksanaan kelas ibu hamil, 10 orang diberikan materi tentang anemia pada kehamilan.

Pendidikan Kesehatan tentang anemia pada ibu hamil merupakan salah satu upaya untuk mencegah anemia pada ibu hamil. Oktaviani dan Meyasa (2018) menunjukkan bahwa pengetahuan tentang anemia merupakan salah satu faktor risiko kejadian anemia pada Ibu hamil. Media yang digunakan untuk menyampaikan informasi merupakan salah satu faktor yang mempengaruhi proses pelaksanaan kegiatan Pendidikan Kesehatan. Lebih lanjut, Susanti et al. (2015) menyatakan bahwa Media informasi yang disampaikan secara menarik, dapat membantu penerima informasi mudah menerima dan mempelajari pesan yang disampaikan sehingga mengadopsi perilaku positif. 


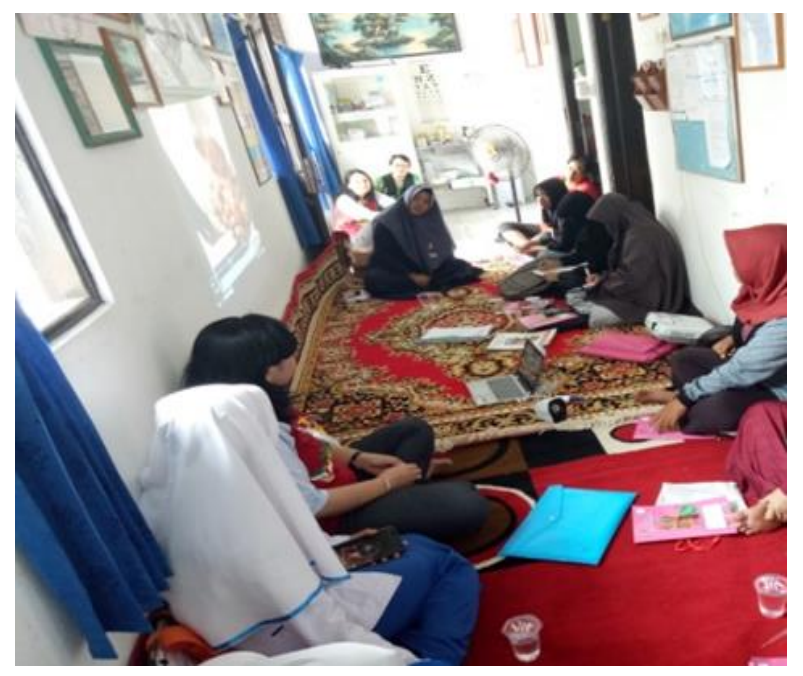

Gambar 1. Pendidikan Kesehatan pada Kelas Ibu Hamil dengan Media Video

Hasil yang didapatkan melalui kegiatan pengabdian masyarakat dengan kelas ibu hamil ini didapatkan tambahan informasi tentang anemia pada masa kehamilan meliputi pengertian anemia, penyebab anemia, proses terjadinya anemia dan dampak anemia pada kehamilan, persalinan dan pasca persalinan. Selain itu, mendapatkan informasi ibu hamil juga saling berinteraksi dan berbagi pengalaman selama menjalani kehamilan saat ini maupun pengalaman sebelumnya.

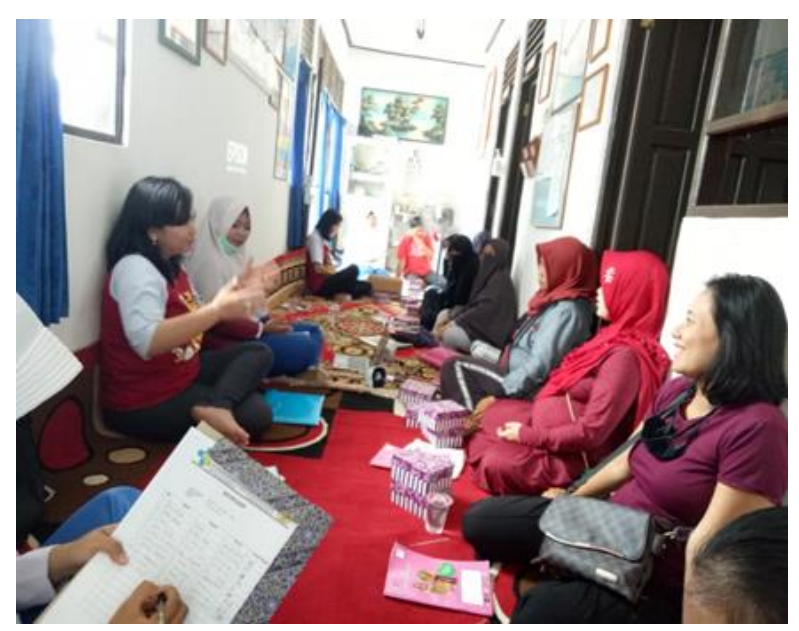

Gambar 2. Interaksi pada Kelas Ibu Hamil

Berikut hasil gambaran hasil nilai pre dan post test ibu hamil sebagaimana disajikan pada Tabel I. Hasil tersebut menunjukkan terdapat peningkatan hasil dari pengetahuan ibu hamil tentang anemia pada kehamilan.
Media video merupakan salah satu alternatif media yang efektif dapat digunakan meningkatkan pengetahuan ibu hamil dan kalangan remaja (Nurhidayati \& Pratiwi, 2013; Oktaviani \& Rarome, 2018; Susanti et al., 2015).

Tabel I. Hasil Pre dan Post Test Ibu Hamil

\begin{tabular}{ccc}
\hline Kegiatan & Nilai & Keterangan \\
\hline Pre Test & $<70$ & 8 orang \\
& $\geq 70$ & 2 orang \\
\hline Post Test & $<70$ & - \\
& $\geq 70$ & 10 orang \\
\hline
\end{tabular}

\section{KESIMPULAN}

Ibu hamil yang menjadi sasaran kegiatan pengabdian masyarakat mendapat informasi tentang anemia pada kehamilan. Kegiatan ini meningkatkan pengetahuan ibu hamil sebesar $80 \%$. Selain itu, kegiatan kelas ibu hamil juga sangat bermanfaat bagi ibu hamil karena meningkatkan interaksi dan sarana untuk berbagi informasi. Kegiatan pengabdian masyarakat selanjutnya, diharapkan untuk terus memberikan motivasi kepada ibu hamil untuk tetap mengikuti kelas ibu hamil untuk meningkatkan pengetahuan ibu hamil untuk mencegah anemia pada masa kehamilan.

\section{UCAPAN TERIMA KASIH}

Terima kasih kepada Dinas Kesehatan Kota Palangka Raya dan Kepala Puskesmas Jekan Raya dan Bidan Puskesmas Pembantu Bumi Palangka, yang telah memberikan ijin dan memfasilitasi kegiatan pengabdian kepada masyarakat.

\section{REFERENSI}

Alini, A., Indrawati, I. 2018. Efektifitas Promosi Kesehatan Melalui Audio Visual Dan Leaflet Tentang SADARI (Pemeriksaan Payudara Sendiri) Terhadap Peningkatan Pengetahuan Remaja Putri Tentang SADARI di SMAN 1 Kampar Tahun 2018. Jurnal Ners. 2(2):1-9. https://doi.org/10.31004/jn.v2i2.187 
Dinas Kesehatan Kota Palangka Raya. 2018. Profil Kesehatan Palangka Raya 2018. Palangka Raya: Dinas Kesehatan Kota Palangka Raya

Natalia, S., Sumarmi, S., Nadhiroh, S.R. 2016. Cakupan ANC dan Cakupan Tablet Fe Hubungannya dengan Prevalensi Anemia di Jawa Timur. Media Gizi Indonesia. 11(1):70-76. http://dx.doi.org/10.20473/mgi.v11i1.70-76

Nurhidayati, D., Pratiwi, T.I. 2013. Pengembangan Media Video Untuk Meningkatkan Pemahaman Bahaya Seks Bebas Di Kalangan Remaja SMA Negeri 1 Soko Tuban. Jurnal BK Unesa. 1(1):281-290.

Oktaviani, O. 2018. Faktor asupan zat besi dan sosio ekonomi dengan kejadian anemia pada ibu hamil. Jurnal Skala Kesehatan: Politeknik Kesehatan Banjarmasin. 9(1):1-6. https://doi.org/10.31964/jsk.v9i1.145

Oktaviani, O., Meyasa, L. 2018. Hubungan Pengetahuan dan Status Gizi Ibu Hamil terhadap Risiko Anemia Ibu Hamil di Puskesmas Kereng Bangkirai. Jurnal Surya Medika (JSM). 4(1):3643. https://doi.org/10.33084/jsm.v4i1.348

Oktaviani, O., Rarome, M.J. 2019. Peningkatan Pengetahuan dan Sikap Ibu Hamil tentang Anemia pada Kehamilan dengan Media Video dan Lembar Balik. Jurnal Kesehatan Metro Sai Wawai. 12(1):56-62. http://dx.doi.org/10.26630/jkm.v12i1.1784

Sukmawati, S., Mamuroh, L., Nurhakim, F. 2019. Pengaruh Edukasi Pencegahan Dan Penanganan Anemia Terhadap Pengetahuan Dan Sikap Ibu Hamil. Jurnal Keperawatan BSI. 7(1):42-47.

https://doi.org/10.31311/jk.v7i1.4689

Susanti, E., Sutedja, E., Madjid, T.H., Husin, F., Idradinata, P.S., Setiawati, E.P. 2015. Perbandingan Penggunaan Media Video Dan Metode Ceramah Dampak Perilaku Seksual Pranikah Terhadap Pengetahuan Dan Sikap Remaja Di Kabupaten Rejang Lebong. Jurnal Pendidikan dan Pelayanan Kebidanan Indonesia (IJFMC (Indonesian Journal of Education and Midwifery Care). 2(3):52-59. http://dx.doi.org/10.24198/ijemc.v2i3.60

Tanziha, I., Damanik, M.R.M., Utama, L.J., Rosmiati, R. 2016. Faktor Risiko Anemia Ibu Hamil di Indonesia. Jurnal Gizi dan Pangan. 11(2):143-
152.

https://doi.org/10.25182/jgp.2016.11.2.\%25p 